\title{
QUALITY OF LIFE IN ADOLESCENTS WITH DISABILITIES
}

\section{Qualidade de vida em adolescentes com deficiência}

\author{
Vanthauze Marques Freire Torres(1), Sandra Conceição Maria Vieira(1)
}

\begin{abstract}
Purpose: to evaluate the perception of quality of life of adolescent students with physical disabilities, visual and hearing. Methods: this was a descriptive and cross-sectional study with 98 adolescents between 10 and 19 years, in 26educational institutions of the state public Recife-PE. To evaluate quality of life was used the assessment tool abbreviated quality of life of the world health organization. For data analysis, we used descriptive and inferential statistics, applying the Mann-Whitney and Kruskal-Wallis test, $p<0.05$. Results: we observed a lower perception of quality of life domains and the global environment and adolescents with physical disabilities in relation to the visually and hearing impaired. As regards the fields, both among the disabled, visual and auditory, the lowest scores were given the environment. The highest scores presented for the disabled, visual and auditory were in social relations. The school entered in a special room, female and non-resident parents obtained with a lower perception of quality of life in the psychological, environmental, social and global quality of life. Conclusion: adolescents with disabilities placed in special rooms presented themselves as the most vulnerable group in the perception and overall quality of life in the psychological, social and environment among students investigated, suggesting the need for public awareness and improving the accessibility and safety of this population.
\end{abstract}

KEYWORDS: Quality of Life; Adolescent; Disabled Persons; Visually Impaired Persons; Hearing Loss

\section{INTRODUCTION}

According to the International Convention on the Rights of People with Disabilities, instituted by Decree $N^{\circ} 6.949$ of August 25, 2009, one can conceptualize as people with disabilities those ones who have long-term physical, mental, intellectual or sensory restraints, which, in interaction with several barriers, might hinder their full and effective participation in society on an equal basis with others ${ }^{1}$.

The World Health Organization (WHO) defines quality of life (QOL) as "the perception of the individual towards its position in life in the context of culture and system of values in which it is inserted and in relation to its objectives, expectations, standards and concerns"2. Within this wider concept,

(1) Faculdade de Odontologia de Pernambuco da Universidade de Pernambuco - FOP/UPE, Recife, Pernambuco, Brasil.

Research Group in People with Disabilities, Post-Graduation Program in Hebiatry (Adolescent Care), Faculty of Dentistry of Pernambuco at the University of Pernambuco - FOP/UPE

Conflict of interest: non-existent the use of subjective instruments that include selfperception and self-assessment of all the factors involved is considered a quick and efficient option for the investigation of well-being ${ }^{3}$.

Among these research instruments, the Short Form of the World Health Organization Quality of Life (WHOQOL-Bref) ${ }^{4}$ has been used to know the quality of life in various world populations, including adolescents. Awasthi et al., in two studies ${ }^{5,6}$, checked the QOL of Indian adolescent students and tested the validity of the instrument PedsQL compared with the WHOQOL-Bref. Thus, it was found that the older adolescents and students from public schools had a lower perception of QOL and observed that, although the PedsQL is a valid and reliable instrument, the WHOQOL-Bref proved to be better to know the QOL of the Indian adolescents. Cheuk et al. ${ }^{7}$, in Hong Kong, analyzed the QOL in adolescents with thalassemia and found different perceptions of QOL between adolescents submitted to transplantations and those who used the conventional treatment, highlighting lower scores of QOL for the physical and environmental domains. Teixeira et al. ${ }^{8}$, upon studying Portuguese adolescents with 
congenital cardiac disease, found that the environmental dimension and the social relationships were the ones that achieved the highest scores, while the physical dimension had lowest score. Kamp-Becker et al. ${ }^{9}$, upon investigating the QOL of adolescents with autism, found that the lowest score assessed was the domain of social relationships, while the greater was the physical domain.

In Brazil, Pires et al. ${ }^{10}$, upon assessing and comparing the QOL of adolescent professional models and those who were not models, found that, despite the similarities between the two groups, the adolescent professional models showed higher perceptions of QOL in the psychological domain. Gordia et al. ${ }^{11-14}$, upon analyzing the QOL by means of the use of the WHOQOL-Bref in adolescent students, found differences between the genders in the environment, psychological and physical domains, investigating their relationships with sociodemographic variables. Interdonato and Greguol $^{15}$, upon analyzing the perception of QOL and of physical activity habits and factors associated to lifestyle in adolescents with visual and hearing impairments, found that adolescents have a good perception of quality of life and showed satisfactory levels of practice of physical activity; thus, it was not observed differences between the perceptions of adolescents with visual and hearing impairments.

Nonetheless, there is a scarcity of studies that characterize the $\mathrm{QOL}$ in adolescents with disabilities. The detailing of this analysis by sociodemographic and disability might help to identify the most critical aspects and most vulnerable groups, which, in turn, might help to determinate the most effective ways of control. Thus, this study was aimed at assessing the perception of quality of life of adolescent students with physical, visual and hearing impairments.

\section{METHODS}

The project of the present study was submitted to the Ethics Committee of the University of Pernambuco - UPE, under the case $n^{\circ} 150 / 11$ and registration in CAAE $n^{\circ}$ 0137.0.097.000-11. All participants were clarified about the research objectives and signed the Free and Informed Consent Form (FICF). In the case of people under 18 years of age, the FICF was signed by the responsible.

This is a descriptive study, with cross-sectional cutting, conducted between June and August 2012, applied to students from schools belonging to the state education network, located in the municipality of Recife-PE.

The study population was composed of 98 adolescents distributed in 26 public education institutions, between 10 and 19 years of age, with physical, visual or hearing impairments, enrolled and truly attending school in a regular manner during the study period.

The minimum sample size was calculated by taking into consideration a sampling error of $5 \%$, an interval of $95 \%$ confidence $(95 \% \mathrm{Cl})$, greater standard deviation among the variables of interest, based on the pilot study in $\pm 24,16$ and plus $20 \%$ in the light of possible losses in the collection process ${ }^{16}$.

Students were selected by simple random sampling, considering the proportionality between the enrollments of students with physical, visual and hearing impairments, provided by the Education Department of the State of Pernambuco (SEDUC/ $\mathrm{PE})^{17}$. In order to replace the selected student, when it was not present in school at the time of collection or in case of refusal, we performed a new draw based on the list of students. We opted for this strategy to minimize replacement sample losses in certain schools with small amount of enrolled students with disabilities. Adolescents with mental and multiple disabilities were excluded from this research.

An adapted questionnaire by Aragon et al. ${ }^{18}$ was used to collect demographic data, covering sociodemographic questions. Subsequently, the Short Form of the World Health Organization Quality of Life (WHOQOL-Bref), developed by the Group Quality of Life from the World Health Organization (WHO), was applied, being that its version in Portuguese was validated and adapted to the parlance and culture by Fleck et al. ${ }^{19}$. The instrument composed of 26 (twenty six) questions, distributed in four (4) domains: physical, psychological, social relationships and environment. The domains are represented by various facets and their questions were formulated for a Likert type response scale, with intensity scale (nothing-extremely), capacity (nothing- completely), frequency (never-always) and assessment (very dissatisfied-very satisfied; very bad-very good). According to Fleck et al. ${ }^{20}$, the instrument is self-explanatory and might be selfadministered, assisted by the interviewer or, even, administered by interviewer.

The application of the instruments was conducted in a differentiated manner among adolescents with visual, physical and hearing impairments. Among students with visual and physical disabilities, the instruments were applied in the form of interviews, administered by the researcher. Students with physical or visual disabilities who do not speak, i.e., with hearing impairments, were excluded from the research, because they had two associated disabilities, which characterize them as students with multiple disabilities, thereby meeting the criteria for exclusion from the research. In students with hearing disabilities, the instrument was self-administered 
with the aid of an interpreter of the Brazilian Sign Language (known as LIBRAS) coming from the educational institution itself to hold dialogue between researchers and participating students.

The data obtained in the WHOQOL-Bref were scored through the use of the statistical program Statistical Package for Social Sciences (SPSS), version 20.0, as suggested by $\mathrm{WHO}^{4}$. Firstly, we resorted to descriptive analysis in order to characterize the sample, making use of absolute and relative frequencies, as well as measurements of central tendency presented by median and interquartile range. Secondly, in order to compare the results of the perceived quality of life in each one of the domains and the sociodemographic characteristics among the groups or categories of variables, we made use of the non-parametric inferential statistical tests Mann-Whitney $U$ and Kruskal-Wallis, with a significance level of 0,05 . The justification for the choice of these tests was due to the lack of evidence on the hypothesis of the normality of the data and the reduced sample sizes.

\section{RESULTS}

It was observed that, of the 98 adolescents who comprised the sample, $81(88,1 \%)$ had hearing impairments, $9(9,1 \%)$ were visually impaired and 8 $(8,2 \%)$ were disabled. Regarding the age group, 55
$(56,1 \%)$ were included between the range from 15 to 19 years and $43(43,9 \%)$ were between 10 and 14 years of age. With regard to gender, $59(60,2 \%)$ were male and $39(39,8 \%)$ were female (Table 1$)$.

By considering the origin of the disability, 81 $(82,7 \%)$ of the surveyed adolescents had congenital disabilities and $17(17,3 \%)$ developed their disabilities after birth. Regarding the schooling level, $85(86,7 \%)$ were in Elementary School II and 13 $(13,3 \%)$ in High School. Concerning the study room, $86(87,8 \%)$ of the students at stake were attending regular classrooms and $12(12,2 \%)$ were in special classrooms (Table 1).

When considering aspects such as living with parents, number of residents and family income, it was observed that $74(75,5 \%)$ of the adolescents were living with their parents, $60(61,2 \%)$ had until 4 residents at their homes and $49(50,0 \%)$ received up to 4 minimum wages (Table 1 ).

Regarding the domains of QOL, both among adolescents with hearing impairments and among the ones with visual and physical impairments, the lowest presented scores were those related to environment (Table 2). The higher scores perceived among the adolescents with physical and hearing impairments were in social relationships, being that the group of visually impaired presented the same high perception in scores to the domains "psychological" and "social relationships" (Table 3). 
Table 1 - Distribution of sociodemographic characteristics of adolescents with physical, visual and hearing impairments $(n=98)$

\begin{tabular}{|c|c|c|c|c|c|c|c|c|}
\hline \multirow{3}{*}{ Variables } & \multicolumn{8}{|c|}{ Type of disability } \\
\hline & \multicolumn{2}{|c|}{ Physical $(n=8)$} & \multicolumn{2}{|c|}{ Visual $(n=9)$} & \multicolumn{2}{|c|}{ Hearing $(n=81)$} & \multicolumn{2}{|c|}{ Total $(n=98)$} \\
\hline & $\mathrm{n}$ & $\%$ & $\mathrm{n}$ & $\%$ & $\mathrm{n}$ & $\%$ & $\mathrm{n}$ & $\%$ \\
\hline \multicolumn{9}{|l|}{ Age } \\
\hline 10 to 14 years & 4 & 50,0 & 3 & 33,3 & 36 & 44,4 & 43 & 43,9 \\
\hline 15 to 19 years & 4 & 50,0 & 6 & 66,7 & 45 & 55,6 & 55 & 56,1 \\
\hline \multicolumn{9}{|l|}{ Gender } \\
\hline Male & 5 & 62,5 & 6 & 66,7 & 48 & 59,3 & 59 & 60,2 \\
\hline Female & 3 & 37,5 & 3 & 33,3 & 33 & 40,7 & 39 & 39,8 \\
\hline \multicolumn{9}{|l|}{ Origin } \\
\hline Acquired & 2 & 25,0 & 3 & 33,3 & 12 & 14,8 & 17 & 17,3 \\
\hline Congenital & 6 & 75,0 & 6 & 66,7 & 69 & 85,2 & 81 & 82,7 \\
\hline \multicolumn{9}{|l|}{ Schooling } \\
\hline Elementary School II & 5 & 62,5 & 6 & 66,7 & 74 & 91,4 & 85 & 86,7 \\
\hline High School & 3 & 37,5 & 3 & 33,3 & 7 & 8,6 & 13 & 13,3 \\
\hline \multicolumn{9}{|l|}{ Classroom } \\
\hline Regular & 8 & 100,0 & 9 & 100,0 & 69 & 85,2 & 86 & 87,8 \\
\hline Special & 0 & 0 & 0 & 0 & 12 & 14,8 & 12 & 12,2 \\
\hline \multicolumn{9}{|l|}{ Regional management } \\
\hline Recife (South) & 4 & 50,0 & 3 & 33,3 & 18 & 22,2 & 25 & 25,5 \\
\hline Recife (North) & 4 & 50,0 & 6 & 66,7 & 63 & 77,8 & 73 & 74,5 \\
\hline \multicolumn{9}{|l|}{ Housing } \\
\hline $\begin{array}{l}\text { Parents (Father + mother) } \\
\text { Mãe) }\end{array}$ & 5 & 62,5 & 6 & 66,7 & 63 & 77,8 & 74 & 75,5 \\
\hline Mother & 2 & 25,0 & 2 & 22,2 & 9 & 11,1 & 13 & 13,3 \\
\hline Other relatives & 1 & 12,5 & 1 & 11,1 & 9 & 11,1 & 11 & 11,2 \\
\hline \multicolumn{9}{|l|}{ Income } \\
\hline Up to four wages & 5 & 62,5 & 4 & 44,4 & 40 & 49,4 & 49 & 50,0 \\
\hline Five or more wages & 3 & 37,5 & 5 & 55,6 & 41 & 50,6 & 49 & 50,0 \\
\hline \multicolumn{9}{|l|}{ Residents } \\
\hline Up to four people & 5 & 62,5 & 5 & 55,6 & 50 & 61,7 & 60 & 61,2 \\
\hline Five or more people & 3 & 37,5 & 4 & 44,4 & 31 & 38,3 & 38 & 38,8 \\
\hline
\end{tabular}

Table 2 - Descriptive analysis of the quality of life of all the surveyed adolescents with disabilities $(\mathrm{n}=98)$

\begin{tabular}{lcccc}
\hline & \multicolumn{4}{c}{ Quality of life } \\
\cline { 2 - 5 } & 1st Quartile & 2nd Quartile & 3rd Quartile & 4th Quartile \\
\hline Physical Domain & 60,71 & 67,86 & 79,46 & 100,00 \\
Psychological Domain & 58,33 & 66,67 & 75,00 & 100,00 \\
Social Domain & 50,00 & 75,00 & 83,33 & 100,00 \\
Environmental Domain & 43,75 & 56,25 & 65,63 & 100,00 \\
Global QOL & 56,15 & 66,11 & 75,24 & 99,22 \\
\hline
\end{tabular}


Table 3 - Global quality of life and domains of the Short Form of the research instrument World Health Organization Quality of Life of adolescents with physical, visual and hearing impairments $(n=98)$

\begin{tabular}{ccccc}
\hline \multirow{2}{*}{ Domains } & \multicolumn{4}{c}{ Disability } \\
\cline { 2 - 5 } & Physical & Visual & Hearing & p \\
\hline Physical & $58,92 \pm 23,22$ & $64,29 \pm 17,85^{\mathrm{a}}$ & $71,43 \pm 21,43^{\mathrm{a}}$ & 0,031 \\
Psychological & $60,41 \pm 7,30$ & $75,00 \pm 29,17$ & $66,67 \pm 14,58$ & 0,091 \\
Social & $62,50 \pm 43,75$ & $75,00 \pm 33,34$ & $75,00 \pm 33,33$ & 0,247 \\
Environment & $43,75 \pm 17,97$ & $56,25 \pm 10,94^{\mathrm{a}}$ & $56,25 \pm 21,87^{\mathrm{a}}$ & 0,011 \\
Global QOL & $55,21 \pm 20,67$ & $68,42 \pm 22,49^{\mathrm{a}}$ & $66,82 \pm 18,62^{\mathrm{a}}$ & 0,037 \\
\hline
\end{tabular}

a Statistically different from adolescents with physical disability.

a Through the Kruskal Wallis test.

When compared the domains of the state QOL with the global QOL among the forms of disability, it was observed that the physically disabled people had a lower perception in the physical and environmental aspects and in global QOL in relation to people with visual and hearing impairments, with statistically significant differences $(p<0,05$ ) (Table 3).

When considering the sociodemographic domains and characteristics of all the adolescents of the sample, it was found that students placed in special rooms had a lower perception of QOL in the domains "psychological", "social relationships" and "environment" in relation to students who were attending regular classrooms $(p<0,05)$. The group of female adolescents also showed lower scores in the psychological and environmental domains, as well as the adolescents who did not live with their parents, had their psychological aspect hindered in relation to the others $(p<0,05)$. Regarding the global $\mathrm{QOL}$, it was also observed that the female gender and the ones placed in special rooms had the lowest perceived scores $(p<0,05)$.

\section{DISCUSSION}

The theme QOL encompasses several meanings and concerns the way in which people live, feel and understand their daily lives. The elements that include the assessment of QOL are related to aspects of culture, of history, of social classes, of the set of material and non-material conditions, of differences by age group and of health conditions of individuals and community ${ }^{21,22}$.

The findings of the present study have indicated the environment as the most impaired domain of $\mathrm{QOL}$ among the surveyed adolescents, corroborating the majority of national and international studies that made use of the WHOQOL-Bref, through which the domain "environment" was demonstrated as the most impaired aspect of QOL involving adolescents from different populations $5,6,11-13,15,23$. This finding is worrisome, because some factors that comprise this field cannot be modified by individual actions in an isolated way, depending massively on government investments, since it encompasses pollution, noise, traffic, weather, transportation, recreational opportunities, physical security and protection, in addition to availability of information in their daily lives and the lack of accessibility that generates difficulties in locomotion.

The domain of social relationships was the one that showed the highest scores among people with physical and hearing impairments. In the visually disabled people, besides the social domain, it was realized that the psychological domain reached a high score. Accordingly, the integrative school environment has demonstrated its value in fostering foster self-esteem of adolescents, encouraging them to better cope with their disabilities with no prejudices, generating benefits in their quality of life. In agreement with this finding, the study conducted in India by Agnihotri et al. ${ }^{24}$, with the purpose of testing the psychometric validity of the WHOQOL-Bref, investigated 525 adolescent students, being that the domain of social relationships was also identified as the one with the highest score.

Regarding the analysis of domains and global perception of QOL in the population under study, we have observed significantly lower scores among adolescents with physical disabilities in physical and environmental domains, besides the global QOL, when compared to people with visual and hearing impairments. In other studies involving different populations of adolescents who had no disabilities, it was found that the values for physical domain are higher, which is a different outcome in relation to the current study, which involved adolescents who had physical limitations. These studies also report that the physical domain is a strong contributor to positive QOL among young people ${ }^{10,14}$. In this 
Table 4 - Comparison of sociodemographic factors on quality of life of all adolescents with disabilities $(n=98)$

\begin{tabular}{|c|c|c|c|c|c|}
\hline \multirow{2}{*}{ Variáveis } & \multicolumn{5}{|c|}{ Domains } \\
\hline & Physical & Psychologicall & Social & Environment & Global \\
\hline \multicolumn{6}{|l|}{ Age } \\
\hline 10 to 14 years & $71,43 \pm 21,43$ & $66,67 \pm 12,50$ & $66,67 \pm 33,33$ & $53,13 \pm 21,88$ & $63,95 \pm 17,27$ \\
\hline 15 to 19 years & $67,86 \pm 17,86$ & $70,83 \pm 20,84$ & $75,00 \pm 33,33$ & $56,25 \pm 18,75$ & $66,82 \pm 21,13$ \\
\hline Value of $p^{(1)}$ & 0,283 & 0,572 & 0,492 & 0,720 & 0,880 \\
\hline \multicolumn{6}{|l|}{ Gender } \\
\hline Male & $71,43 \pm 21,43$ & $70,83 \pm 16,67$ & $75,00 \pm 33,33$ & $56,25 \pm 25,00$ & $69,16 \pm 20,61$ \\
\hline Female & $67,86 \pm 17,86$ & $62,50 \pm 16,66$ & $66,67 \pm 33,33$ & $50,00 \pm 21,87$ & $63,95 \pm 19,38$ \\
\hline Value of $p^{(1)}$ & 0,125 & 0,035 & 0,115 & 0,017 & 0,020 \\
\hline \multicolumn{6}{|l|}{ Origin } \\
\hline Acquired & $71,43 \pm 21,42$ & $75,00 \pm 27,08$ & $66,67 \pm 41,67$ & $56,25 \pm 28,12$ & $70,35 \pm 24,43$ \\
\hline Congenital & $67,86 \pm 21,43$ & $66,67 \pm 14,58$ & $75,00 \pm 33,33$ & $56,25 \pm 20,31$ & $65,03 \pm 17,97$ \\
\hline Value of $p^{(1)}$ & 0,749 & 0,601 & 0,773 & 0,778 & 0,888 \\
\hline \multicolumn{6}{|l|}{ Schooling } \\
\hline Elementary School II & $71,43 \pm 21,43$ & $66,67 \pm 12,50$ & $75,00 \pm 33,33$ & $56,25 \pm 23,44$ & $67,04 \pm 18,62$ \\
\hline High School & $64,29 \pm 16,08$ & $62,50 \pm 18,75$ & $66,67 \pm 37,50$ & $50,00 \pm 21,88$ & $61,53 \pm 20,50$ \\
\hline Value of $p^{(1)}$ & 0,180 & 0,171 & 0,536 & 0,101 & 0,220 \\
\hline \multicolumn{6}{|l|}{ Classroom } \\
\hline Regular & $71,43 \pm 21,43$ & $70,83 \pm 16,67$ & $75,00 \pm 33,33$ & $56,25 \pm 21,87$ & $67,47 \pm 18,28$ \\
\hline Special & $66,07 \pm 9,83$ & $60,41 \pm 8,33$ & $50,00 \pm 16,67$ & $46,88 \pm 15,62$ & $54,82 \pm 6,34$ \\
\hline Value of $p^{(1)}$ & 0,081 & 0,001 & 0,010 & 0,030 & 0,004 \\
\hline \multicolumn{6}{|l|}{ Regional management } \\
\hline Recife (South) & $67,86 \pm 26,78$ & $62,50 \pm 18,76$ & $66,67 \pm 33,33$ & $56,25 \pm 29,68$ & $61,35 \pm 26,28$ \\
\hline Recife (North) & $67,86 \pm 19,64$ & $66,67 \pm 16,67$ & $75,00 \pm 33,33$ & $56,25 \pm 18,75$ & $66,82 \pm 15,57$ \\
\hline Value of $p^{(1)}$ & 0,734 & 0,905 & 0,663 & 0,861 & 0,760 \\
\hline \multicolumn{6}{|l|}{ Housing } \\
\hline Parents (Father + mother) & $71,43 \pm 21,43$ & $68,75 \pm 13,54$ & $75,00 \pm 33,33$ & $56,25 \pm 22,66$ & $67,47 \pm 19,06$ \\
\hline Mother & $64,29 \pm 25,00$ & $62,50 \pm 16,66$ & $66,67 \pm 29,16$ & $46,88 \pm 25,00$ & $61,35 \pm 20,92$ \\
\hline Other relatives & $64,29 \pm 14,29$ & $58,33 \pm 16,66$ & $58,33 \pm 33,33$ & $56,25 \pm 18,75$ & $58,41 \pm 20,46$ \\
\hline Value of $p^{(2)}$ & 0,182 & 0,044 & 0,250 & 0,421 & 0,179 \\
\hline \multicolumn{6}{|l|}{ Income } \\
\hline Up to four wages & $67,86 \pm 19,64$ & $66,67 \pm 12,50$ & $75,00 \pm 33,33$ & $56,25 \pm 21,87$ & $66,82 \pm 17,25$ \\
\hline Five or more wages & $67,86 \pm 21,43$ & $62,5 \pm 20,84$ & $75,00 \pm 37,50$ & $56,25 \pm 21,88$ & $66,07 \pm 20,82$ \\
\hline Value of $p^{(1)}$ & 0,784 & 0,484 & 0,380 & 0,921 & 0,782 \\
\hline \multicolumn{6}{|l|}{ Residents } \\
\hline Up to four people & $67,86 \pm 21,43$ & $66,67 \pm 12,50$ & $75,00 \pm 33,33$ & $54,69 \pm 21,10$ & $66,55 \pm 18,32$ \\
\hline Five or more people & $71,43 \pm 17,86$ & $64,58 \pm 21,88$ & $66,67 \pm 35,41$ & $56,25 \pm 25,78$ & $66,11 \pm 22,38$ \\
\hline Value of $p^{(1)}$ & 0,956 & 0,655 & 0,738 & 0,599 & 0,841 \\
\hline
\end{tabular}

(1): Through the Mann-Whitney.

(2): Through the Kruskal Wallis test.

domain, the main items of quality of life are focused on the presence of pain or discomfort, dependence on medication, satisfaction with sleep, ability to work and daily activities, among others. By considering that the selected sample in this study was composed of adolescents with physical, visual or hearing impairments, it was expected that the scores found could suffer some interference arising from the fact that these teenagers have some kind of disability. In this case, the lowest scores found reveal that disabled people have impairments in physical and environmental domains, besides the QOL. In order to corroborate these findings, it should be cited the study of Lin et al. ${ }^{25}$, in which it was observed the changes in self-perception of quality of life and found that, despite the conditions of material wellbeing and health remain constant, the quality of life of adolescents with physical disabilities remained reduced over time, due to the limitations of social activities in older adolescents. 
The results also revealed that adolescents of the female gender significantly showed a lower perception of QOL for the psychological and environmental domains, when compared to adolescents of the male gender. In a study performed by Gordia et al. ${ }^{11}$, which examined the environmental domain of the QOL of 608 adolescent students in the State of Paraná, it was found that adolescents of the female gender was the vulnerable point. Al Feyes and Ohaeri ${ }^{26}$, upon researching 4.467 adolescents in schools located in Kuwait, noted that girls have a lower perception of QOL in the psychological domain, suggesting that school programs developed in friendly study environments can help to promote a better perception in the psychological domain, thereby reducing the symptoms of anxiety and depression that are common among girls.

It was noticed that a small proportion of surveyed adolescents with disabilities $(12,2 \%)$ were inserted in exclusive rooms for disabled people, i.e., special rooms. Studies indicate that inclusion in regular room fosters the exchange of experiences, by establishing meaningful bonds of friendship with other students, which enables them to become active members in the construction of knowledge ${ }^{27,28}$. The separation of students in special room has an important influence in the quality of life of this population, which was observed in the current study, since the adolescents with disabilities in regular rooms significantly showed higher scores in the domains of psychology, environment and social relationships, besides the global QOL, when compared with adolescents with disabilities in special rooms. The school is a crucial environment for the education and socialization of children and adolescents in a development, and school activities bring positive outcomes for the health and well-being of adolescents ${ }^{27,28}$.

Another important finding in this study was the ascertainment that the adolescents who did not live with their parents significantly showed lower scores of QOL in the psychological domain, when compared to adolescents who lived with their respective parents. This finding is in agreement with studies that indicate that the coexistence with parents has an important role in determining human behavior, in developing personality, in the course of moral, in mental evolution and in the establishment of the culture. The parents are seen by adolescents with disabilities as a "safe harbor" and confidants, being that affection, companionship and support are highly appreciated. This relationship is responsible for providing security to the young people, which is a relevant factor for their sense of well-being ${ }^{13,29}$.
The current research has some limitations that should be considered. Of course, it becomes limited to solely review by means of quantifications a concept intrinsically marked by subjectivity, such as the QOL construct. One should keep in mind that the indicators and indexes always measure "aspects" of QOL. Accordingly, the results observed in the present study need to be carefully analyzed, given that the "objective" measurement of QOL was measured in a subjective manner by means of a questionnaire. Nevertheless, it is worth emphasizing that the instrument has been presented as a practical and reliable possibility of analysis of QOL, in addition, the WHOQOL-Bref is recommended by WHO for the assessment of $\mathrm{QOL}^{4}$.

Besides the difficulty to measure the QOL, another limitation of the present study is that the sample was selected in public schools in the municipality of Recife - PE, which, despite having a daily monitoring conducted by the teaching staff of each school, with students often stimulated towards the practice of cognitive and social activities, one can also observe, in several cases, schools with minimal educational structure for students with disabilities. In light of the foregoing, the extrapolation of data to other adolescents receiving another form of monitoring is limited. Lastly, this study showed a cross-sectional design and it is not possible to establish a cause and effect relationship between the disabilities and the QOL of adolescents.

\section{CONCLUSION}

Adolescents with physical disabilities presented themselves as the most vulnerable group in the perception of global QOL in the physical and environmental domains among the surveyed students. The main subgroups with lower perceived scores of QOL were composed of adolescents of the female gender, students coming from special rooms and who did not live with their parents.

The results of this study highlight the public need for improvements in the conditions of accessibility, safety, health care actions and opportunities of learning of new information and skills by adolescents with disabilities, which are required for a fundamental exercise of citizenship.

Thus, we highlight the need for the accomplishment of new studies, in order to determine the way in which the factors, such as, for example, good habits, physical activities and lifestyle, interfere or promote a higher perception of quality of life among adolescents with disabilities. 


\section{RESUMO}

Objetivo: avaliar a percepção da qualidade de vida de adolescentes escolares com deficiência física, visual e auditiva. Métodos: tratou-se de um estudo descritivo e de corte transversal com 98 adolescentes entre 10 e 19 anos, em 26 instituições de ensino público estadual do Recife-PE. Para avaliação da qualidade de vida foi utilizado o questionário de avaliação abreviado da qualidade de vida da organização mundial de saúde. Para análise dos dados, foi utilizada a estatística descritiva e inferencial, aplicando-se os testes Mann-Whitney e Kruskal-Wallis, com $p<0,05$. Resultados: observou-se uma menor percepção da qualidade de vida global e nos domínios meio ambiente e físico dos adolescentes com deficiência física em relação aos deficientes visuais e auditivos. No tocante aos domínios, tanto entre os deficientes físicos, visuais e os auditivos, os menores escores apresentados foram os do meio ambiente. Os maiores escores apresentados para os deficientes físicos, visuais e auditivos foram nas relações sociais. Os escolares inseridos em sala especial, do gênero feminino e não residentes com os pais obtiveram uma menor percepção da qualidade de vida nos domínios psicológico, meio ambiente, relações sociais e qualidade de vida global. Conclusão: os adolescentes com deficiência inseridos em salas especiais apresentaram-se como o grupo mais vulnerável na percepção da qualidade de vida global e nos domínios psicológico, social e meio ambiente entre os escolares investigados, sugerindo a necessidade de atenção pública e melhoria das condições de acessibilidade e segurança desta população.

DESCRITORES: Qualidade de Vida; Adolescente; Pessoas com Deficiência; Pessoas com Deficiência Visual; Perda Auditiva

\section{REFERENCES}

1. BRASIL. Decreto n. 6.949 , de 25 de agosto de 2009a. Disponível em: <http://www.planalto.gov. br/ccivil_03/_ato2007-2010/2009/decreto/d6949. htm>. Acesso em: 23 jan. 2013.

2. The WHOQOL Group. The World Health Organization Quality of LifeAssessment(WHOQOL): position paper from the World Health Organization. Social Science and Medicine. 1995;41(10):1403-9.

3. Bowling A. Mode of questionnaire administration can have serious effects on data quality. J Public Health (Oxf). 2005;27(3):281-91.

4. The Whoqol Group. Development of the World Health Organization WHOQOL-bref. Quality of Life Assesment 1998. Psychol Med. 1998;28:551-8.

5. Awasthi S, Agnihotri K, Singh U, Thakur S, Chandra $\mathrm{H}$. Determinants of health related quality of life in school-going adolescents in Northern India. Indian J Pediatr.[Internet]. 2011[cited 2013 Oct 28];78(5):555661. Available from: http://www.ncbi. nlm.nih.gov/pubmed/21267797.

6. Awasthi S, Agnihotri K, Chandra H, Singh U, Thakur S. Assessment of Health-Related Quality of Life in school-going adolescents: validation of PedsQL instrument and comparison with WHOQOL-BREF. [BVS]. Natl Med J India [Internet]. 2012 [cited 2013 Jan 12];25(2):74-9. Available from: http://pesquisa. bvsalud.org/regional/resources/mdl-22686712.
7. Cheuk DKL, Mok ASP, Lee ACW, Chiang AKS, Ha SY, Lau YL, et al. Quality of life in patients with transfusion-dependent thalassemia after hematopoietic SCT. Bone Marrow Transplant [Internet]. 2008 [cited 2013 Oct 28];16;42(5):319-27. Available from: http://dx.doi.org/10.1038/ bmt.2008.165.

8. Teixeira FM, Coelho RM, Proença C, Silva AM, Vieira D, Vaz C. Quality of life experienced by adolescents and young adults with congenital heart disease. Pediatric cardiology [Internet]. 2011 Dec [cited 2012 May 27];32(8):1132-8. Available from: http://www.ncbi.nlm.nih.gov/pubmed/21710181.

9. Kamp-Becker I, Schröder J, Remschmidt H, Bachmann CJ. Health-related quality of life in adolescents and young adults with high functioning autism-spectrum disorder. GMS Psycho Social Medicine. 2010;7:1-10.

10. Pires L, Rodrigues AM, Fisberg M, Costa RF, Schoen TH. Qualidade de vida de adolescentes modelos profissionais. PsicTeor e Pesq [serial on the Internet]. 2012 Jan/Mar [cited 2013 Jan 05]; 28(1):71-6. Available from: http://www.scielo. br/scielo.php?script=sci_arttext\&pid=S010237722012000100009\&lng=en\&tlng=pt. http://dx.doi. org/10.1590/S0102-37722012000100009.

11. Gordia AP, Quadros TMB, Campos W, Vilela Jr GB. Qualidade de vida de adolescentes da rede particular de ensino: comparação entre gêneros. Rev Bras qualidade de vida. 2009;1(2):16-24. 
12. Gordia AP, Quadros TMB, Campos W. Variáveis sociodemográficas como determinantes do domínio meio ambiente da qualidade de vida de adolescentes. Ciênc. saúde coletiva [periódico na Internet]. 2009 Dez [citado 2013 Jan 10]; 14(6): 2261-8. Disponível em: http://www.scielo. $\mathrm{br} /$ scielo. $p h p$ ?script $=\mathrm{sci}$ arttext\&pid=S1413$81232009000600035 \&$ Ing=pt. $\quad$ http://dx.doi. org/10.1590/S1413-81232009000600035.

13. Gordia AP, Silva RCR, Quadros TMB, Campos W. Variáveis comportamentais e sociodemográficas estão associadas ao domínio psicológico da qualidade de vida de adolescentes. Rev. paul. pediatr. [serial on the Internet]. 2010 Mar [cited 2013 Jan 13]; 28(1):29-35. Available from: http://www. scielo.br/scielo.php?script=sci_arttext\&pid=S010305822010000100006\&lng=en. http://dx.doi. org/10.1590/S0103-05822010000100006.

14. Gordia Alex Pinheiro, Quadros Teresa M Bianchini de, Campos Wagner de, PetroskiÉdio L. Domínio Físico da Qualidade de Vida entre Adolescentes: Associação com Atividade Física e Sexo. Rev. salud pública [serial on the Internet]. 2009 Feb [cited 2013 Jan 12]; 11(1):50-61. Available from: http://www.scielosp.org/ scielo.php?script=sci_arttext\&pid=S012400642009000100006\&lng=en.

http://dx.doi. org/10.1590/S0124-00642009000100006.

15. Interdonato GC, Greguol, M. Qualidade de vida e prática habitual de atividade física em adolescentes com deficiência. Rev. bras. Crescimento desenvolv. hum. [Internet]. 2011 [cited 2013 Oct 28];21(2):282-95.Available from:http://www.revistas. usp.br/jhgd/article/download/20016/22102.

16. Luiz RR, Magnanini MF. Alógica da determinação do tamanho da amostra em investigações epidemiológicas. Cad Saúde Colet. 2000;8:9-28.

17. Secretaria de Educação de Pernambuco [SEDUC PE]. Censo escolar de 2011, Disponível em: http://www.educacao.pe.gov.br (acessado em 05 de maio de 2012).

18. Aragão AKR, Souza A, Silva K, Vieira S, Colares, $\mathrm{V}$. Acessibilidade da criança e do adolescente com deficiência na atenção básica de saúde bucal

Received on: September 03, 2013

Accepted on: December 08, 2013

Mailing address:

Vanthauze Marques Freire Torres

Rua Antônio Carlos Ribeiro de Andrade, $n^{\circ}$ 63, Apt

302 - Iputinga

Recife - Pernambuco - Brasil

CEP: 50680-080

E-mail: vanthauze@hotmail.com do serviço público: um estudo piloto. Pesq. Bras odontoped clin integr. 2011;11(2):159-64.

19. Fleck MPA, Louzada S, Xavier M, Chachamovich E, Vieira G, Santos L, Pinzon V. Aplicação da versão em português do instrumento abreviado de avaliação da qualidade de vida "WHOQOL-bref". Rev. Saude Publica. 2000;34(2):178-83.

20. Fleck MPA. O instrumento de avaliação de qualidade de vida da Organização Mundial da Saúde (WHOQOL-100): características e perspectivas. Rev Ciênc Saúde Colet. 2000;5(1):33-8.

21. Seidl EMF, Zannon C. Qualidade de vida e saúde: aspectos conceituais e metodológicos. Cad Saude Publica. 2004;20(2):580-8.

22. Minayo MCS, Hartz ZMA, Buss, PM. Qualidade de vida e saúde: um debate necessário. CiênSaude Colet. 2000;5(1):7-18.

23. Izutsu T, Tsutsumi A, Islam A, Matsuo Y, Yamada $\mathrm{HS}$, Kurita $\mathrm{H}$, Wakai $\mathrm{S}$. Validity and reliability of the Bangla version of WHOQOLBREF on an adolescent population in Bangladesh. Qual Life Res. 2005;14(7):1783-9.

24. Agnihotri K, Awasthi S, Chandra $H$, Singh U, Thakur S. Validation of WHOQOL-BREF instrument in Indian adolescents. Indian Journal of Pediatrics. 2010;77(4):381-6.

25. Lin J-H, Ju Y-H, Lee S-J, Yang Y-H, Lo SK. Examining changes in self-perceived quality of life in children and adolescents with physical disability using a longitudinal design. Disability and rehabilitation. [Internet]. 2011 Jan [cited 2012 Sep 10];33(19-20):1873-9. Available from: http://www. ncbi.nlm.nih.gov/pubmed/21309649.

26. Al-Fayez GA, Ohaeri JU. Profile of subjective quality of life and its correlates in a nation-wide sample of high school students in an Arab setting using the WHOQOL-Bref. BMC Psychiatry. [Internet]. 2011 [cited 2013 Oct 28];11(71):1-12. Available from: http://www.pubmedcentral.nih.gov/ articlerender.fcgi?artid=3098152\&tool=pmcentrez\& rendertype $=$ abstract.

27. Novaes RG, Trugillo EA. O aluno surdo no contexto do ensino regular. Rev Eventos Pedagógicos. 2011;2(2):210-9.

28. Santos LHC, Grisotto KP Rodrigues DCB, Bruck I. Inclusão escolar de crianças e adolescentes com paralisia cerebral: esta é uma realidade possível para todas elas em nossos dias?. Rev. paul. pediatr. [Internet]. 2011 [cited 2013 Oct 28];29(3):314-9.Available from: http://www.scielo. $\mathrm{br} / \mathrm{pdf} / \mathrm{rpp} / \mathrm{v} 29 \mathrm{n} 3 / \mathrm{a} 02 \mathrm{v} 29 \mathrm{n} 3 . \mathrm{pdff}$.

29. Young B, Rice H, Dixon-Woods M, Colver AF, Parkinson KN. A qualitative study of the healthrelated quality of life of disabled children. Dev Med Child Neurol. [Internet]. 2007 [cited 2013 Oct 28];49(9):660-5. Available from: http://www.ncbi. nlm.nih.gov/pubmed/17718821. 